\title{
De middeleeuwse parochie in het graafschap Vlaanderen tijdens de volle middeleeuwen. Een overzicht.
}

\author{
Marc Carnier
}

De middeleeuwse parochie kan bezwaarlijk het geliefde onderzoeksterrein van generaties kerkhistorici worden genoemd. Zowel in binnen- als buitenland kregen bisdommen en op lager niveau abdijen en kapittels een veel ruimere aandacht ${ }^{1}$. Deze instellingen lieten een meer homogeen bronnenmateriaal na en konden dan ook in al hun facetten bestudeerd worden. Middeleeuwse parochies lieten geen bronnen na. De inlichtingen over middeleeuwse bidplaatsen en parochies komen dan ook steeds uit bestanden die ons maar secundair hierover inlichten. In concreto gaat het hier, althans tot in de dertiende eeuw, over archieven afkomstig van de bezitters van de parochie : abdijen en kapittels. De inlichtingen zijn evenwel niet schaars, wel disparaat en verborgen achter een zekere techniciteit van de terminologie. Tenslotte werd en wordt de middeleeuwse parochie nog altijd bekeken vanuit haar huidige of in het beste geval haar posttridentijnse werking, waardoor een aantal actoren hetzij onderbelicht blijven (bv de bezitter) of te sterk benadrukt worden (bisschop en kerkelijke hiërarchie in het algemeen). Dit is deels te begrijpen door het feit dat bijna alle functies en niveaus die toen bestonden ook nu nog bestaan : parochie, bisschop, deken, pastoor, kerkfabriek, parochianen. Het verschil is echter dat de invulling van deze begrippen sterk verschilt, vooral omdat de verhoudingen tussen de verschillende actoren anders lagen.

Het is de bedoeling om in deze bijdrage voor de regio van het graafschap Vlaanderen na te gaan wat het onderzoek naar de parochies heeft opgeleverd en tegelijk een kader mee te geven aan de onderzoeker die met de oudste kerkelijke situatie geconfronteerd wordt. Hiervoor maak ik vooral gebruik van de eigen bevindingen tijdens met doctoraatsonderzoek ${ }^{2}$. Geografisch beperk ik me tot de bisdom-

1 Cf. bijvoorbeeld de zeer geringe plaats die de parochie in het overzicht van DE MOREAU inneemt: Histoire de l'église en Belgique, 5 delen, Brussel, 1945-52.

2 M. CARNIER, Bidplaatsen en parochies in het bisdom Terwaan vóór 1300: een institutionele studie, 2 delen, onuitgegeven doctoraatsverhandeling K.U.Leuven, 1996. Het spreekt voor zich dat hier in deze bijdrage het notenapparaat noodgedwongen beperkt werd. 
men van het graafschap Vlaanderen, de bisdommen Terwaan, Doornik en Atrecht en in mindere mate Kamerijk.

Het graafschap Vlaanderen heeft in tegenstelling met het hertogdom Brabant voor zijn onderzoek naar parochies geen Verbesselt gekend. De programmaverklaring waarin Verbesselt de krachtlijnen voor zijn latere magnum opus formuleerde, dateert van 1950 en hij is hierin vooral schatplichtig aan het werk van kanunnik Laenen uit $1924^{\text {s }}$, die zelf voor de oudste periode in de traditie van Stutz en vooral Imbart de la Tour werkte. Verbesselt zelf besteedde onder andere veel aandacht aan de geografie waarin hij elementen meende te zien die over de ouderdom van de parochie konden beslissen. De hele cyclus van Verbesselt brengt een schat aan gegevens naar voor en is in die zin zeer verdienstelijk, maar enig dogmatisme in zijn redeneringen is hem niet vreemd. Het aantal merowingische parochies bijvoorbeeld dat Verbesselt kon onderscheiden is ongetwijfeld een krachttoer. Het is echter problematisch om de ouderdom van parochies te meten door het optellen van een aantal elementen (vorm van de parochie, patroonheilige, eerste vermelding, tiendenverdeling...), nog los van het feit of er in onze streken überhaupt iets bestond als merowingische parochies. In ieder geval is een dergelijke systematische behandeling van de parochies voor het graafschap Vlaanderen nooit gebeurd. Het beperkt zich meestal tot een aantal, zij het vaak verdienstelijke, pagina's in een dorpsmonografie $^{5}$.

3 J. LAENEN, Introduction à l'histoire paroissiale du diocèse de Malines. Les institutions, Brussel, 1924.

4 P. IMBART DE LA TOLR, Les paroisses rurales du 4e au 11e siècle, Parijs, 1900; U. STUTZ, Die Eigenkirche als Element des mittelalterlich-germanischen Kirchenrechts, Berlijn, 1895 (herdruk, Darmstadt, 1955).

5 O.a. J. VAN ACKER, Geschiedenis van Adinkerke tot in de 19 e eeuw, in: N. DESIERE, red, 1000 jaar Adinkerke, 992-1992, s.1., 1993, 11-29; M. COORNAERT, Dudzele en Sint-Lenaart. De geschiedenis, de topografie en de toponimie van Dudzele tot omstreeks 1914, met een sludie over de Sint-Lenaartsommegang, Dudzele, 1985; M. DENDUYVR red., Gestella 1988: duizend jaar Gistel, Gistel, 1988; E. HUYS, Geschiedenis van Gheluwe, Kortrijk, 1891; A. VERVENNE en A. DHONT, Geschiedenis van Loppem, Loppem, 1974; A. VERVENNE, De parochie Sint-Martinus en haar pastoors van 1300 tot heden, Loppem, 1980; B. MEIJNS, De stad Oudenburg. Een synthese van haar eerste tien eeuwen, onuitgegeven licentiaatsverhandeling, Leuven, 1993; P. VANDEPITTE, Tiell, speuren naar heden en verleden van Tiel, Aarsele, Kanegem en Schuiferskapelle, Ticlt, Weesp, 1985; L. RUBBRECHT, Geschiedenis van Waton, Handzame, 1983 (anast. herdruk van 1910); V. PIL, Zonnebeke, Heerlijk verleden en zonnig heden, Langemark, 1962; J. COLPAERT, Avelgem voor 1500, Avelgem, 1965. 
Internationaal hebben middeleeuwse parochies echter de laatste twee decennia de nodige aandacht gekregen, vooral in Frankrijk en in iets mindere mate in Duitsland en Italie ${ }^{6}$. Een aantal internationale colloquia hebben het onderzoek sterk bevorderd ${ }^{7}$ en tegelijk verschenen verscheidene synthesewerken ${ }^{8}$. De grootste vooruitgang gebeurde echter in het kader van het onderzoek naar middeleeuwse bisdommen, vooral in Frankrijk en meestal in het kader van een doctorat d'état. Het gaat omdermeer om de studies van Michel Aubrun voor het bisdom Limoges (1981), van Jacques Avril voor het bisdom Angers (1984) en belangrijker voor ons Bernard Delmaire voor het bisdom Atrecht (verdedigd 1988, gepubliceerd 1994) ${ }^{9}$. De Rijselse hoogleraar Bernard Delmaire bestudeerde voor zijn doctorat d'état het religieus leven van het bisdom Atrecht in al zijn facetten, dus ook het parochiale niveau. Als bijlage gaf hij ondermeer een repertorium van alle parochies van het bisdom Atrecht. Net als voor de andere bisdommen die door zijn collega's werden bestudeerd, is een diepgaander onderzoek naar de parochie binnen het bisdom echter nog steeds mogelijk $\mathrm{k}^{10}$. Naar aanleiding van een colloquium in het Henegouwse Saint-Ghislain over de parochie gaf Delmaire verder nog een stand van het onderzoek voor de bisdommen Atrecht, Kamerijk, Terwaan en Doornik; zowel deze bijdrage als zijn studie over het bisdom Atrecht zullen in dit overzicht steeds als referentiekader worden gebruikt ${ }^{11}$.

6 De aandacht in Groot-Brittannië daarentegen was minder groot.

7 Le istituzioni ecclesiastiche della socielas christiana dei secoli XI-XII. Diocesi, pievi e parrochie. Alti della sesta settimane internazionale di studio, Milano 1-7 settembre, 1974, Milaan, 1977; Christianizzazione ed organizzazione ecclesiastica delle campagna nell'alto medioevo: espansione e resistenze. Settimane di studio del centro Italiano di studi sull'alto medioevo, XXVIII, 10-16 aprile, 1980, Spoleto, 1982; L'encadrement religieux des fidèles au Moyen-Age et jusqu'au Concile de Trente. La paroisse, le clergé, la pastorale, la dévotion. Actes du 109 e congrès national des sociétés savantes, Dijon, 1984, Parijs, 1985; La paroisse en Languedoc (XIII-XTVe s.). Cahiers de Fanjeaux 25, Toulouse-Fanjeaux, 1990.

8 M. ALBRUN, La paroisse en France, des origines au XIVe siécle, Parijs, 1986; V. BO, Storia della parrochia, 4 delen, Rome, 1990-92.

9 M. AUBRUN, L'ancien diocèse de Limoges des origines au milieu du XIe siècle, ClermontFerrand, 1981; J. AVRIL, Le gouvernement des évêques et la vie religieuse dans le diocèse d'Angers (1148-1240), 3 delen, Rijsel, 1984; B. DELMAIRE, Le diocèse d'Arras de 1093 au milieu du XIVe siècle. Recherches sur la vie religieuse de la France au Moyen Age, 2 delen, Atrecht, 1994.

10 Cf. M. CARNIER, Het bisdom Atrecht: tien jaar historiografie, in: Signum, X (1998), 51-56 met verwijzing naar een paar recensies.

11 B. DELMAIRE, Les paroisses rurales du 11 e au 15 siècle dans les diocèses d'Arras, Cambrai, Tournai en Thérouanne: état de la question, in: La paroisse en questions. Des origines à la fin de l'ancien régime. Actes du colloque de Sainl-Ghislain, 25 novembre 1995, Ath, Bergen, Saint-Chislain, 1998, 49-92. Voor het bisdom Luik cf. de studies van 


\section{Wat is een parochie?}

Historici en canonisten zijn het erover eens dat vier elementen noodzakelijk zijn om over een parochie te kunnen spreken. Een parochie moet ten eerste beschikken over een eigen bidplaats, een parochiekerk die zich door de diensten die er plaats vinden duidelijk onderscheidt van een afhankelijke bidplaats (kapel). Aan deze parochiekerk is bovendien een eigen patrimonium verbonden. Het tweede element is dat een parochie een eigen vrij nauwkeurig afgelijnd territorium is. Deze afbakening was in de eerste plaats nodig om de inning van de tienden zonder al te veel conflicten te laten verlopen. Een parochie bezit ten derde vast kerkelijk personeel, met name de parochiepriester die soms werd bijgestaan door één of meerdere helpers. Deze priester werd in principe door de bisschop benoemd en werd door hem met de zielzorg belast. Tenslotte bestaat iedere parochie uit een gemeenschap van gelovigen, de parochianen, waarvan het grootste deel er van doop tot begrafenis de religieuze diensten volbracht ${ }^{12}$.

Deze sluitende definitie is echter in het onderzoek naar de middeleeuwse parochie moeilijk te gebuiken. Het bronnenbestand laat vooreerst niet toe deze vier elementen cumulatief na te gaan. Het is namelijk onmogelijk om deze definiëring voor het einde van de middeleeuwen toe te passen op een individuele, mogelijke parochie. Voor een aantal parochies belanden we zelfs al diep in de zeventiende eeuw vooraleer alle elementen met zekerheid kunnen worden geattesteerd. Bovendien is deze statische definitie, die zeker opgaat voor de dertiende eeuw, weinig geschikt om de lange evolutie van het parochiaal systeem daarvóór aan te duiden.

Het is belangrijk om voor ogen te houden dat er geen middeleeuwse definitie van een parochie bestaat. Ook het canonieke recht verstrekt hierover maar disparate informatie. Pas met het concilie van Trente kreeg het begrip parochie zijn eigen kerkrechterlijke invulling. De parochie is dus een instelling die in de praktijk is gegroeid

A. DIERKENS, Abbayes et chapitres entre Sambre et Meuse (VIIe-XIe siècles). Contribution à l'histoire des campagnes du Haut Moyen Age (Beihefte der Francia 14), Parijs, Sigmaringen, 1985 (Het deel van zijn doctoraat dat hij in 1983 aan de ULB verdedigde dat over de parochies gaat is hierin echter maar partieel opgenomen), van M. VAN REY, Die Lütticher Gaue Condroz und Ardennen im Frühmittelalter zur Pfarrorganisation, Bonn, 1977 en nog steeds te gebruiken L. HAI.KIN, Introduction à l'histoire paroissiale de l'ancien diocèse de Liège. Les institutions, Brussel, 1935.

12 Cf. J. GAUDEMET, Le gouvernement de l'église à l'époque classique, Ile partie. Le gouvernement local, Parijs, 1979, 224. 
en die praktijk werd slechts gedeeltelijk door het kerkelijk recht gevolgd ${ }^{13}$.

Er zijn echter een aantal andere elementen die ons gegevens over het statuut van de bidplaats kunnen verschaffen. Zo worden bidplaatsen die doop- en begrafenisrecht hebben door veel auteurs als parochiekerken aanzien. Dopen en begraven in een bidplaats zijn zeker belangrijke aanwijzingen, maar vormen geen sluitend criterium. Geschreven gegevens over dooprecht en archelogische over doopkapellen zijn voor het graafschap Vlaanderen zeer zeldzaam ${ }^{14}$. Bovendien zijn er ook elders voorbeelden gevonden van parochiekerken die geen dooprecht hadden. Normaal zijn er meer gegevens te vinden over kerkhoven, over het begrafenisrecht en vooral over de conflicten daarrond, maar die zijn zelden van vóór de veertiende eeuw. In een niet gering aantal bidplaatsen werd overigens begraven zonder dat ze een parochiaal statuut hadden. Denken we maar aan de vele abdij- en kloosterkerken.

Een ander criterium om parochies te onderscheiden is het tiendrecht of de tiendplicht ${ }^{15}$. Binnen het territorium van een parochie werden de tienden gebruikt voor de materiële uitbouw van de parochie. Binnen dit territorium kon de priester zijn jurisdictie laten gelden en kon hij beschikken over zekere inkomsten. Dat was althans de bedoeling van de karolingische machtshebbers die het systeem van de tiendeninning verplicht stelden. Vermeldingen van tienden op lokaal vlak zijn voor de elfde eeuw eerder zeldzaam, maar daarna worden ze overvloedig. In de elfde en twaalfde eeuw is de band tussen tienden en parochie echter zo los geworden dat het als criterium om een parochie te onderscheiden nog weinig betrouwbaar is. Inning van tienden blijft een belangrijk criterium maar er zijn voorbeelden van tiendengebieden die zich over twee of meerdere

13 Cf. J. AVRIL, Quelques aspects de l'institution paroissiale après le IVe concile du Latran, in: Crises et réformes dans l'église, de la réforme Grégorienne à la préréforme. Actes du 115e congrès national des sociétés savantes.Avignon, 1990, Parijs, 1991, 93-94.

14 In tegenstelling met bijvoorbeeld grote delen van het bisdom Luik, cf. A. DIERKENS, Les paroisses rurales dans le nord de la Gaule pendant le haut moyen âge. État de la question et remarques critiques, in La paroisse en questions. Des origines à la fin de l'ancien régime. Actes du colloque de Saint-Ghislain, 25 novembre 1995, Ath, Bergen, SaintGhislain, 1998, 31-33.

15 Cf. infra.

16 Het was zelfs geen bezwaar dat één tiende zich over twee bisdommen uitstrekte zoals een tiende die deels in Zonnebeke (bisdom Terwaan), deels in Passendale (bisdom Doornik) lag (M. CARNIER, Parochies en bidplaatsen in het bisdom Terwaan vóór 1300. Een repertorium van de parochies van de dekenijen Veurne en Ieper en een overzicht van alle bidplaatsen van het bisdom, Brussel, 1999, 277). 
parochies uitstrekten of van een tiendengebied dat tot een blijkbaar niet meer functionerende parochie behoorde ${ }^{16}$.

Misschien kan de toen gebruikte terminologie ons verder helpen. De term parrochia (paroisse, prochie) werd zoals bekend aanvankelijk gebruikt om het hele bisdom weer te geven. Die betekenis bleef in hele Westen lange tijd actief, maar geleidelijk werden alle kerkelijke territoria hiermee benoemd. Vanaf de tiende, elfde eeuw werd het nog quasi uitsluitend voor het laagste kerkelijke niveau, de huidige parochie, gebruikt. Voor het bisdom Terwaan is dat bijvoorbeeld circa 960 in een narratieve bron en 1040 in een oorkonde ${ }^{17}$. Parrochia werd in Terwaan, Doornik en de omringende bisdommen echter vrij weinig gebruikt en dan nog bijna uitsluitend in de betekenis van een territorium waarin iets gelokaliseerd moest worden. De termen die in onze regio in het bronnenmateriaal gebruikt werden, verwijzen eerder naar de bidplaats. Het gaat om termen als altare, ecclesia en in mindere mate capella. Altare is in de Noordfranse bisdommen van de elfde tot het midden van de dertiende eeuw de meeste gebruikte term voor een bidplaats en had een specifieke betekenis. De bezitter van dit altare had recht op één derde van de tienden en een deel van de offergaven. Het complement van dit altare was het bodium of de twee overige derden van de tienden (duae partes decimae). Deze terminologie is ook topografisch te begrijpen. Het altare of het koor van de kerk was het deel waar de geestelijkheid het voor het zeggen had, het bodium of het schip van de kerk was dat deel dat tot de leken behoorde, in casu ab origine de dorpsheer ${ }^{18}$. Het feit dat met deze termen expliciet de inning van tienden wordt aangeduid, is, zoals gezegd, een belangrijke aanwijzing dat het om een parochiekerk gaat. Toch zijn er voorbeelden van altaria te vinden die geen parochiekerk waren ${ }^{19}$. Ecclesia is een term die voor alle niveaus en voor alle instanties binnen de Westerse kerk werd gebruikt. Op lokaal niveau kan ecclesia zowel een abdij of een kapittel of gelijk welke bidplaats aanduiden. Het is in die gevallen meestal een neutrale term die ons weinig over het statuut van de bidplaats leert. De term verschijnt dan ook vooral in bronnen die niet in de NoordFranse bisdommen zijn opgesteld of die er althans niet mee ver-

17 FOLCUINUS, Gesla abbalum Sancti Bertini Sithiensium, O. HOLDER-EGGER ed, in: MGII, SS, XIII, 1881, 617; D. HAIGNERÉ ed., Les charles de Saint-Bertin d'après le grand carlulaire de Dom Charles-Joseph Deanitte, I, Saint-Omer, 1886, 23 (nr. 70).

18 L. VOET, Bodium-Redecima, in Archivum Latinitatis Medii Aevi, XX (1950) 207-44; A.VERHULST, Ieper in de 11 de-12de eeuw, in R. OPSOMMER red., Van Ieperse scholen en lenen, schilderijen en criminelen, uit velerlei eeuwen, Ieper, 1999, 350-351. 
trouwd zijn. Ecclesia had in het graafschap Vlaanderen echter ook nog een heel specifieke technische betekenis die we ondermeer in de bekende oorkonde van het Sint-Donaaskapittel van Brugge van 1089 terugvinden $^{20}$, namelijk als de optelling van altare en bodium. De bezitter van het ecclesia had zo recht op de drie derden van de tienden, op het presentatierecht en op een deel van de offergaven (alta$r e+$ bodium $=$ ecclesia $)^{21}$. Capella is een term die bijna altijd werd gebruikt voor een afhankelijke bidplaats, hoewel er ook hier een paar uitzonderingen bekend zijn. Een probleem kan bijvoorbeeld zijn dat capella (of het variant in de volkstaal) tot een vast deel van het toponiem was versteend ${ }^{22}$. Andere termen die ook nog gebruikt werden voor een afhankelijke bidplaats zijn membrum, appendicium en succursus.

In het algemeen geeft de terminologie die voor de bidplaats werd gebruikt belangrijke aanwijzingen, maar geen enkele term is als criterium volledig betrouwbaar. Ook de terminologie van de parochiepriester kan een aantal aanwijzingen geven. In de bisdommen Terwaan, Doornik en Atrecht wordt de bedienaar aanvankelijk doorgaans simpelweg presbyter genoemd ${ }^{23}$. In de dertiende eeuw wordt dit geregeld presbyter parrochialis ${ }^{24}$, zodat er in dit geval geen discussie meer is of het om de parochiepriester gaat. Termen als sacerdos, plebanus, rector en pastor worden vóór 1300 eerder zelden gebruikt ${ }^{25}$. Curatus verschijnt pas vanaf het midden van de dertiende eeuw, maar wordt vanaf dan frequent gebruikt ${ }^{26}$. Ook het middelnederlandse

19 DELMAIRE, Arras, 64.

20 M. GYSSEIING en A. KOCH ed., Diplomatica belgica ante annum millesimum centesimum scripta, Brussel, 1950, 295-298 (nr. 170).

21 CARNIER, Repertorium, 40, 59-63, 102-106 en 248.

22 Cf. de vele "-kapelle" $n$ in de polderregio: bv. Armbouts-Cappel, Avekapelle, Eggewaartskapelle, Sint-Jacobskapelle, Wallon-Cappel, Wemaers-Cappel, Zegerscappel.

23 Bijvoorbeeld M. VLEESCHOUWERS-VAN MELKEBEEK ed., Documenten uit de praktijk van gedingbeslissende rechtspraak van de officialiteit van Doornik. Oorsprong en vroege ontwikkeling (1192-1300), Brussel, 1985, 14 (nr. 8: magister Philippus, presbiter de Ostborg) en 32 (nr. 21: presbiter de Morselede) en 33 (nr. 22: magister Johannes, presbiter de Beverna) en verder CARNIER, Repertorium, passim en DELMAIRE, Arras, 146.

24 B.v. VLEESCHOUWERS-VAN MELKEBEEK ed., Documenten, 29 (nr. 19: presbiter parrochialis Sancti Mauricii Insulensis) en CARNIER, Repertorium, 63, 159, 221, 229, 254.

25 B.v. CARNIER, Repertorium, 91 (plebanus); 159, 161, 225, 227, 271 (rector); 227, 241 (sacerdos).

26 B.v. VLEESCHOUWERS-VAN MELKEBEEK ed., Documenten, 73 (nr. 56: Jacobus, ipsius ecclesie curatus), 88 (nr. 67: presbiteri curati Sancti Michaelis Gandensis) en 56; CARNIER, Repertorium, 46, 73, 74, 119, 141, 159, 161, 164, 172, 180, 186, 188, 222, $229,241,247,271$. 
pape wordt vanaf het einde van de dertiende eeuw vrij veel gebruikt ${ }^{27}$. Een zekere vertrouwdheid met de terminologie geeft in ieder geval belangrijke aanwijzingen of het om een parochiepriester gaat, maar ook hier is er zelden een absolute zekerheid ${ }^{28}$.

$\mathrm{Al}$ deze elementen tezamen geven uiteraard een zeer sterke aanwijzing of een bepaalde bidplaats een parochiekerk is, zonder dat er weliswaar één absoluut en steeds geldig criterium bestaat. Voorzichtigheid is in de beoordeling dus steeds geboden. Pas met de eerste pouillés hebben we meer zekerheid. Dit zijn taxatielijsten van de beneficies van een bisdom waarvan de oudste voor de NoordFranse bisdommen van het midden van de veertiende eeuw dateren $^{29}$. Hierin zijn in principe ook alle parochies opgenomen. Nu zijn deze pouillés niet volledig foutloos noch perfect uitgegeven en niet altijd even gemakkelijk te interpreteren, maar globaal geven ze toch een nauwkeurige lijst van alle parochies van een bisdom. Daarvóór is het onmogelijk om het aantal parochies van een bisdom te kennen. Vertrekkend vanuit de pouillés kunnen we regressief teruggaan tot minstens de helft van de twaalfde eeuw. In de bronnen van de twaalfde en dertiende eeuw duiken echter vele bidplaatsen op die op dezelfde manier werden benoemd als de andere, maar die niet in de pouillés terug te vnden zijn.

\section{Wanneer en hoe zijn parochies ontstaan ?}

We kunnen stellen dat uit de bronnen van het einde van de elfde eeuw, begin twaalfde eeuw ongetwijfeld blijkt dat er een "parochiaal systeem" bestond. Hoe lang dit in onze streken reeds bestond en onder welke vorm is veel moeilijker te zeggen, want dit hangt nauw samen met het voorgaande deel, namelijk hoe moeten we een parochie definiëren en hoe kunnen we dit in de bronnen verifiëren ? Het is voor de regio van het graafschap Vlaanderen in het beste geval na te gaan of er een bidplaats bestond, niet of er een parochie was. Om de schaarste van het bronnenmateriaal aan te tonen, is het misschien goed om te vermelden dat er voor de Karolingische periode van amper 18 bidplaatsen van het bisdom Terwaan een eigentijdse geschreven bevestiging bestaat. Het bronnenmateriaal is dus ontoereikend om doorgedreven onderzoek te doen vóór het einde van de

27 vb CARNIER, Repertorium, 132 en 208, 222.

28 Voor de bediening cf. infra.

29 Uitgegeven door A. LONGNON ed., Pouillés de province de Reims, I, Parijs, 1887. 
elfde eeuw. Vlaanderen is bovendien een regio waarin ook de archeologische gegevens over kerken zeer zeldzaam zijn omdat men aanvankelijk in hout bouwde en we zelden de ouderdom van de bidplaats langs deze weg kunnen achterhalen.

Onderzoek naar de ontstaansperiode van een bidplaats is mogelijk langs een aantal wegen, maar het weze duidelijk dat het resultaat eerder op het niveau van mogelijkheid dan van zekerheid zal liggen. De resultaten moeten steeds met de nodige terughouding bekeken worden. Tenslotte zullen de resultaten eerder informatie over de bidplaatsen van een bepaalde regio verschaffen dan over aparte bidplaatsen. Het gebrek aan geschreven bronnen kan deels gecompenseerd worden door de gegevens die de studie van de patroonheilige van de kerk, de toponymie, de historische geografie en de archeologie verschaffen. De studie van de patroonheiligen of Patrozinienforschung heeft ook hier zijn bestaansrecht verworven, hoewel er tot nog toe weinig systematische studies zijn gebeurd. Baanbreker voor het graafschap Vlaanderen was Geert Berings met zijn studie over de patroonheiligen van het Scheldebekken ${ }^{30}$. Zijn onderzoek en eigen onderzoek voor het bisdom Terwaan brengt een aantal interessante gegevens over de christianisatie ${ }^{31}$ aan het licht, maar de individuele patroonheilige van een kerk dateren is niet mogelijk. De meeste patroonheiligen bleven te lang actief en voor de mogelijke keuze zijn er verschillende verklaringen mogelijk. Patroonheiligen als Sint-Maarten en Sint-Pieter zijn interessant om de christianisatie na te gaan, maar zijn niet te gebuiken als datering voor een individuele bidplaats. Zo verwijst het Martinusvocabel vaak naar kerken die door de frankische adel gesticht zijn en het Petrusvocabel eerder naar monastieke stichtingen, maar beide bewegingen zijn sterk gelijklopend en in geen geval tegenstrijdig. Andere patrocinia zijn preciezer te dateren. Het bekendste voorbeeld is SintNiklaas, dat in het Westen pas na 1087 (de translatie van zijn relieken naar Bari) actief werd. Sint-Niklaaskerken zijn in principe nooit ouder. Kerken veranderden echter ook vroeger wel eens van patroonheilige. In het algemeen zijn patroonheiligen van kerken vrij

30 G. BERINGS, Les patronages de saints dans la vallée de l'Escaut. Esquisse d'une méthode de recherche sur la christianisation, in Revue du Nord, LXVIII (1986) 433-444.

31 Sint-Maarten was zowel in het bisdom Terwaan als in het bisdom Atrecht goed voor één zesde van alle patroonheiligen van de kerk, Sint-Pieter in Terwaan 10\%, in Atrecht 7,5\%; O.L.V. in beide bisdommen voor 10\%. (DELMAIRE, Arras, 90). De volledige lijst van de patrocinia voor het bisdom Terwaan zijn te vinden in CARNIER, Repertorium, 381-385. 
consistent, maar wijzigingen kwamen desalnietttemin voor en misschien wel meer dan men tot nog toe aanneemt $t^{32}$. De studie wordt tenslotte ook bemoeilijkt door het ontbreken van systematisch onderzoek naar verspreiding en datering van de verering van de heiligen.

Toponymisch en geografisch onderzoek levert op zijn beurt elementen over de nederzettingsgeschiedenis en over de bidplaats die daar eventueel bij verbonden was. Nadeel is dat dit zeer arbeidsintensief onderzoek geen bevredigende resultaten garandeert ${ }^{33}$.

Archeologische resten zijn zoals gezegd in deze steenarme streek zeer zeldzaam. Bovendien zorgde de relatieve rijkdom van het graafschap in latere episoden ervoor dat de kerken ook vrij veel verbouwd en vergroot werden. De opgravingen in de kerken die tot nog toe werden verricht, brengen maar heel zelden gegevens van vóór 1000 aan het licht. Zelfs de archeologische resultaten van de bisschopsstad Terwaan zijn op kerkhistorisch gebied teleurstellend ${ }^{34}$.

In andere, zelfs naburige regio's, worden ook elementen voor het bepalen van de ouderdom van de bidplaats en de vorming van het parochiaal systeem uit het latere statuut van de bidplaats gehaald en uit de grootte en de vorm van de latere parochie. Vooral in het bisdom Luik zien we dat de bidplaatsen waren ingedeeld in ecclesia integra, ecclesia dimidia (of media) en quarta capella ${ }^{35}$. Dit is echter in de eer-

32 In 1735 wist men bijvoorbeeld niet meer wat de oorspronkelijke patroonheilige van de kerk van Balinghem was (bisdom Terwaan, dekenij Guînes) (G. BELLART e.a., Paroisses el communes de France. Dictionnaire d'histoire administrative el démographique. Pas-de-Calais, Rijsel-Parijs, 1975, s.v.).

33 De betere voorbeelden zijn G. BERINGS, Het oude land aan de rand van het vroegmiddeleeuwse overstromingsgebied van de Noordzee. Landname en grondbezit tijdens de middeleeuwen, in Handelingen der maatschappij voor geschiedenis en oudheidkunde te Genl, XXXIX (1985) 37-84 en IDEM, Landschap, geschiedenis en archeologie in het Oudenaardse, Oudenaarde, 1989; A. WAEGEMAN, Een onderzoek naar het ontstaan van Zonnebeke en haar kerk, in Ilet Zonneheem, III (1985) 66-79 en IV (1986) 16-30, 49-60 en 82-90.

34 R. DELMAIRE, Étude archéologique de la partie orientale de la cité des Morins (civitas Morinorum), Atrecht, 1976. Voor de architecturale resten cf. B. FIRMIN, De romaansche kerkelijke bouwkunst in West-Vlaanderen, s.1., 1940; L. DEVLIEGHER, De opkomst van de kerkelijke gotische bouwkunst in West-Vlaanderen gedurende de XIII eeuw, in Bulletin van de Koninklijke Commissie voor Monumenten en Landschappen, V (1954) $177-345$ en VII (1956) 7-121; IDEM, De kerkelijke romaanse bouwkunst in FransVlaanderen, in Bulletin van de Koninklijke Commissie voor Monumenten en Landschappen, 9 (1958), 3-125. Franse résumé: IDEM, L'architecture romane de la Flandre française au nord de la Lys, in Mélanges offerts à René Grozet, Poitiers, 1966, 499-506

35 DIERKENS, Paroisses rurales, 42-45. 
ste plaats een economisch onderscheid, gemaakt op basis van de hoogte van de taks die men aan de bisschop of de aartsdiaken moest, en zonder noodzakelijke consequentie voor de juridische status van de kerk. Het is wel zo dat men er op basis van deze indeling in geslaagd is, moeder -en dochterparochies van elkaar te onderscheiden. Zo zijn ecclesiae integrae zelden dochterkerken en quartae capellae zelden moederkerken. Het is moelijk om deze kerken absoluut te dateren, maar een relatieve datering is wel vaak mogelijk. Deze benamingen als weergave van een ecomische onderscheid bestaan echter niet voor de bisdommen Terwaan, Doornik en Atrecht. Het zoeken naar moeder- en dochterparochies is hier eerder delicaat. Een paar kunnen we achterhalen via het bestaande bronnenmateriaal, maar van het grootste deel hebben we geen enkel idee. Ook gegevens op basis van de vorm van de parochie waarmee bijvoorbeeld Aubrun voor de studie van het bisdom Limoges ${ }^{36}$ tot mooie resultaten kwam, zijn voor noordelijke bisdommen amper te gebuiken. Hoe noordelijker gelegen, hoe minder de vorm van de latere parochie belang heeft. Dit is te verklaren door het feit dat christianisatie er vaak samenviel met kolonisatie en dus een stuk later en minder systematisch is gebeurd. Een 'parochiale' structuur is in onze streken vermoedelijk niet ouder dan de Karolingische periode. Het zoeken naar Merowingische parochies in onze streken heeft dan ook weinig zin ${ }^{37}$. Het onderzoek naar afhankelijke bidplaatsen is bovendien iets dat in een ruimer kader moet worden onderzocht. We kennen tot nog toe te weinig van de oudere domaniale structuren waarvan we kunnen veronderstellen dat de bidplaats op deze domeinen de latere parochiale kerk is geworden, om een idee van de afhankelijkheid van de bidplaatsen te krijgen. En om iets over de stichters van de bidplaatsen te weten, zouden we ook veel beter de vroegmiddeleeuwse sociale structuur moeten kennen. In datzelfde kader lijkt het onderscheid dat sommige auteurs in navolging van Imbart de la Tour zoeken tussen villa en vicuskerken mij voor de noordelijke bisdommen met een geringe Romeinse invloed weinig zinvol ${ }^{38}$. Dit onderscheid werd gemaakt in de besluiten van de concilies en synoden van de zesde en zevende eeuw en verwees dus naar de toenmalige toestand van het geromaniseerde en dus gechristianiseerde deel van Gallië.

36 Cf. supra noot 9 .

37 J. NOTERDAEME, De fiscus Snellegem en de vroegste kerstening in het westen van Brugge, in Handelingen der maatschappij voor geschiedenis en oudheidkunde te Gent, XI (1957), 49-130.

38 LAENEN, Introduction, 50-63. 
Het is voor deze zuidelijke delen al moeilijk om dit normatieve kader in de praktijk te toetsen, laat staan voor het noordelijke deel dat nog amper gechristianiseerd was. In Noord-Gallië was zeker een sterke domaniale structuur, maar het bestaan van juridisch onafhankelijke dorpen is al veel moeilijker te attesteren ${ }^{39}$. Bovendien hebben vele auteurs uit onze streken geprobeerd om dit schema van Imbart de la Tour blindelings toe te passen op lokale situaties zonder dat het bronnenmateriaal daar enige aanleiding toe gaf. Het schema van Imbart, namelijk dat er aanvankelijk één moederkerk was voor het hele bisdom, de kerk van de bisschop zelf, en dat met de christianisatie van het platteland een aantal parochiekerken zich van de bisschopskerk loskoppelde, wordt om één of andere reden nog steeds niet ter discussie gesteld. Er is bovendien nog een praktisch probleem in verband met het onderzoek naar de vorm van de parochie, dus naar de grenzen van de parochie. Gemakkelijkshalve kan in grote lijnen uitgegaan worden van de gemeentegrenzen zoals die in de Franse tijd ontstonden en grotendeels tot aan de fusies bleven voortbestaan. Het is alleen de vraag of dit wel aan de middeleeuwse realiteit beantwoordde. Waren parochiegrenzen bovendien wel zo belangrijk tijdens de volle middeleeuwen en beantwoordden ze aan de vroegere domaniale structuren ? Het traceren van de vroegere parochiegrenzen is een arbeidsintensief onderzoek dat grondige kennis van de lokale toponymie vereist en bovendien -alweer-niet noodzakelijk tot succesrijke resultaten leidt. Het is dus onderzoek waarin vooral lokale historici de nodige aanzetten moeten geven. Globaal kunnen we stellen dat de bisdommen Terwaan, Doornik en Atrecht qua bronnenmateriaal zeker niet ideaal zijn om naar de onderlinge afhankelijkheid van de bidplaatsen te zoeken. De vraag is bovendien of het eigenlijk wel zo belangrijk is om vanuit de studie van een parochiaal systeem de onderlinge afhankelijkheid te achterhalen, als blijkt dat deze afhankelijkheid in de bestudeerde bisdommen geen enkele invloed had op de juridische positie van de bidplaats, en dus op de diensten die er in die bidplaats plaats vonden. We ontmoeten in het bronnenmateriaal van de elfde, twaalfde eeuw een bestaand 'parochiaal' systeem, waar zich nog enkel een paar kleinere wijzigingen zullen voordoen. Over die kleinere aanpassingen aan het systeem zijn we beter ingelicht. Het gaat met name over het ontstaan van de polderparochies en van de parochies op andere

39 In tegenstelling met bijvoorbeeld J. FOSSIER, La terre et les hommes en Picardie jusqu'à la fin du XIIle siècle, Parijs, Leuven, 1968. In de Karolingische concilies en capitularia worden vicuskerken nog amper vermeld. 
woeste grond $^{40}$ in de bisdommen Terwaan en Doornik en over de parochievorming binnen de steden. Ook tijdens de twaalfde en dertiende eeuw werden door de bisschoppen geen 'offficiële' stichtingsoorkonden van een parochie opgesteld. Het blijft dus steeds gaan om informatie uit secundaire bronnen. Voor de polders zijn vooral de studies van Boterberge en Berings belangrijk ${ }^{41}$. Op basis van het oorkondelijk materiaal over de kerkelijke situatie en de historische gegevens over de inpoldering slaagde Boterberge erin om de parochiale ontwikkeling van de polders rond de IJzermonding weer te geven. Spijtig genoeg hield hij echter geen rekening met de bezitters van de parochies, waardoor hij een aantal fouten niet kon vermijden. De bezitter van de moederparochie werd namelijk ook steeds de bezitter van de dochterparochie. Voor een aantal afhankelijkheden gaf hij zelf geen bewijzen, zodat zijn schema verder gaat dan de bestaande informatie dit toelaat ${ }^{42}$. In ieder geval zien we dat in de Veurnse polders het initiatief voor een nieuwe parochie bij de lokale grootgrondbezitters lag zoals de familie van Lampernisse. De naam van de initiatiefnemers leeft of leefde bovendien vaak verder in de naam van de nederzetting : Sheerwillemskapelle, Volcravenkinderskerke (Oostkerke), Avekapelle, Eggewaartskapelle, Reinilinikapelle (Oudekapelle)...

De bezitter had geen problemen met een nieuwe parochie op voorwaarde dat zijn inkomsten er niet door verminderden. De pastoor van de oude moederparochie stemde toe als hij op zijn beurt voldoende compensatie kreeg en de bisschop kwam enkel tussenbeide als er problemen waren en beperkte zich verder tot het inwijden van de nieuwe bidplaats. De krachtlijnen voor het ontstaan van stedelijke parochies zijn gelijkaardig. Ook hier kwam het initiatief vanuit de basis, van één of meerdere burgers die zelf de inkomsten voor de

40 Cf. o.a. A. VERHULST, Woesten: een dorpstichting van Diederik van de Elzas, graaf van Vlaanderen (1161), in HEm, CXXVIII (1991) 47-62.

41 R. BOTERBERGE, Historische geografie van het overstromingsgebied van de IJzer in de Middeleeuwen, in Handelingen der maatschappij voor geschiedenis en oudheidkunde te Gent, XVI (1962) 77-142; BERINGS, Het oude land.

$42 \mathrm{Hij}$ verdeelde de bezittingen van het OLV-kapittel van Saint-Omer tussen die van de Sint-Bertijnsabdij en die van het Brugse Sint-Donaaskapittel. Zo ontstonden volgens hem Alveringem uit Steenkerke en Oudekapelle en Nieuwkapelle uit Esen. In de realiteit was Alveringem een oud bezit van het kapittel van SaintOmer, vergat hij Lampernisse te vermelden die tot hetzelfde kapittel behoorde en die vermoedelijk de moederparochie was van Oudekapelle (BOTERBERGE, 8891). Nieuwkapelle ontstond tenslotte vanuit Lo. Ook de rol van Wulpen als moederparochie van Oostduinkerke, Nieuwpoort en Ramskapelle is niet hard te maken. 
bouw en de werking van de nieuwe bidplaats bijeen brachten. Zo kunnen we voor de Ieperse Sint-Janskerk enkele begunstigers onderscheiden. De Ieperse Sint-Kruiskerk was hoofdzakelijk het werk van één inwoner ${ }^{43}$. Ook hier stemde de bezitter, in Ieper het SintMaartenskapittel, in zolang aan zijn inkomsten niet geraakt werd. Een houding die de bezitter overigens ook aannam tegen de vestiging van niet-parochiale bidplaatsen ${ }^{44}$. Toch bleef een verdere indeling van de parochies in een aantal steden steken, omdat de bezitter een verdere uitbreiding tegenhield. Onderzoek naar de stedelijke parochiale ontwikkeling is dus mogelijk, maar ook hier krijgen we zelden een volledig beeld. Vooral de vraag naar de oudste kerk en moederparochie van de nederzetting is zeer moeilijk op te lossen. Deze vraag heeft zowel voor Ieper, Brugge als Gent reeds veel inkt doen vloeien ${ }^{45}$. De archeologie kan ons hier wel helpen om de ouderdom en de functie van de bidplaats te achterhalen, maar vertelt ons niets over haar juridisch statuut.

Men kan hier dus stellen dat de bisdommen Terwaan en Doornik vanaf de zevende eeuw een net van bidplaatsen kregen, maar dat het meest noordelijk deel zijn christianisatie pas tegen de late achtste eeuw voltooid zag. Wanneer er bij ons sprake was van een 'parochiaal' systeem is onduidelijk, maar in ieder geval niet vóór de negende eeuw. Wanneer de bronnen vanaf de tweede helft van de elfde eeuw talrijker en diverser worden, stellen we vast dat er een parochiaal net bestaat, dat nog relatief weinig wijzigingen zal ondergaan ${ }^{4 i}$. Enkel op die plaatsen waar een bevolkingstoename een uitbreiding van het net toelaat, zullen er tijdens de twaalfde en dertiende eeuw nog enkele nieuwe parochies ontstaan, zoals in nieuw ontgonnen gebieden als de polders en in de steden.

43 M. CARNIER, Het parochiewezen te Ieper to 1300, in De Sint-Maarlenskathedraal te Ieper, 60 jaar kerkwijding 1930-1990, Ieper, 1990, 102-104.

44 M. CARNIER, De houding van het Ieperse Sint-Maartenskapittel tegenover de vestiging van niel-parochiale bidplaatsen vóór 1300, in Wevend aan het verleden, Liber Amicorum O. Mus, Veurne, 1992, 59-68.

45 Cf. M. RYCKAERT, Van ruraal hulpkerkje tot stadskerk. Stichting en oudste geschiedenis van de parochie, in De Onze-Lieve-Vrouwekerk te Brugge, Brugge, 1997, 9-17 versus B. MEIJNS. Een 'valse start' en een omstreden erfenis uit het verleden. De bewogen ontstaansgeschiedenis van het kapittel (1091-einde 12de eeuw), in Ibidem, 19-50. Voor Ieper in laatste instantie VERHULST, Ieper in de 11de en 12 de eeuw.

46 Delmaire stelde vast dat minstens $80 \%$ van de parochiekerken in het bisdom Atrecht in de elfde eeuw reeds bestonden (DELMAIRE, Arras, 72). 


\section{Wie bezat een parochie of bidplaats ?}

De vraag naar het bezit van de parochie of bidplaats is essentieel, maar deze problematiek is complex en moeilijk op een paar bladzijden met alle nodige nuances weer te geven. We zullen ons hier dus noodgewongen beperken tot een aantal krachtlijnen. De gevolgen van dit bezit waren verreikend, maar tegelijk ook moeilijk in te schatten. De hele discussie wordt bovendien bemoeilijkt door een inflatie aan termen die te pas en te onpas worden gebruikt om dit bezit weer te geven : eigenkerk, patronaat, personaat, pastor primitivus, incorporatie... Deze termen worden te vaak gehanteerd vanuit een statisch en anachronistisch idee die men van de parochie heeft en waarbij men voorbijgaat aan de grote dynamiek en de lokale diversiteit die het systeem tot zeker de twaalfde eeuw kenmerkte.

Het vertrekpunt is dat in de laat- en postkarolingische tijd bidplaatsen ofwel in handen waren van kerkelijke, vooral monastieke instanties, of van leken. De bezitter van de grond bezat namelijk ook de bidplaats die erop stond. Deze kerken kregen in de Duitstalige literatuur de term Eigenkirche mee en in de Franstalige literatuur l'óglise privée. De oudere literatuur zag deze constellatie bovendien als een abnormale situatie, met name als een usurpatie van goederen die per definitie kerkelijk waren en waarvan het dus de bedoeling was dat die ooit eens naar de Kerk zouden terugkeren. Het volstaat om een aantal stukken na te lezen om de negatieve termen vast te stellen waarmee het parochiewezen in de late negende en de tiende eeuw wordt beschreven ${ }^{47}$. $\mathrm{Nu}$ is het inderdaad wel zo dat de bidplaatsen van de monastieke domeinen van de abdijen van Sint-Bertijns, SintPieters en Sint-Baafs van Gent bijvoorbeeld aan belangrijke "usurpaties' waren onderworpen. We moeten wel voor ogen houden dat de kerkelijke en de wereldlijke sfeer in die periode en dit tot de late elfde eeuw sowieso niet onderscheiden waren. De chaotische politieke toestand van de late negende en de eerste helft van de tiende eeuw zorgde ervoor dat de abdijen gewoon niet in staat waren hun bidplaatsen te laten functioneren. Het 'overnemen' van vele bidplaatsen door leken was dan ook het beste en het meest logische dat

47 Als voorbeeld een vulgariserend werkje van kanunnik Laenen, Eenige Bladzijden uit de Geschiedenis van het Parochieweren (Verhandelingen van de Algemeene Katholieke Vlanmsche Hongeschooluitbreiding nr. 181), Antwerpen, 1920, 19-21: Omstreeks het jaar 1000 is er verandering op tit. Rust en vrede vervangen in zekere mate de bandeloosheid der vorige eeuwen, en hel godsdienstig gevoel herleeft. Vele heeren, zoo kleine als groote, dorpspotentaten, herlogen en keizers, die onbeschroomd de kerkelijke inkomsten hadden opgestreken, kriggen nu rouwkoop. (p. 21). 
deze bidplaatsen in deze periode kon overkomen. Een aantal domeinen en bidplaatsen keerden dan ook bij een sterker centraal, grafelijk bestuur naar de oorspronkelijke bezitter terug. Zo was in de vroege twaalfde eeuw bekend dat het domein van Poperinge door graaf Arnulf de Grote aan de Sint-Bertijnsabdij werd gerestitueerd ${ }^{14}$. Globaal mogen we vermoedelijk wel stellen, hoewel het bronnenmateriaal absoluut geen zekerheid biedt, dat in de tiende eeuw het grootste deel van de bidplaatsen in lekenhanden was. $\mathrm{Zij}$ streken zeker de inkomsten van de kerk op, maar zorgden er tegelijk ook voor dat de bidplaats functioneerde.

In de elfde eeuw zien we echter een eigenaardig en geografisch beperkt fenomeen opduiken : het systeem van de persona. De eerste serieuze aanzet voor het onderzoek naar de persona dateert uit de jaren twintig, maar pas in het laatste decennium kreeg het onderzoek een belangrijke stimulans door een artikel van de Duitser Wolfgang Petke en door de bisdomsstudie van Bernard Delmaire ${ }^{49}$. Daarvóór werd de persona wel door een hele reeks Belgische historici vermeld, maar de resultaten waren nogal uiteenlopend en door het gebruik van een te beperkt bronnenmateriaal te fragmentair ${ }^{50}$. Het systeem van de persona is geografisch beperkt tot de Noordfranse bisdommen en Neder-Lotharingen. Het bronnenmateriaal kent dus dezelfde beperking. Verder duikt de persona vooral in het bronnenmateriaal op, op het moment dat het systeem over zijn hoogtepunt heen is en geleidelijk wordt opgedoekt. We hebben zo goed als geen bronnen die ons over het ontstaan en de bloei van het systeem inlichten. Deze beperkingen bepalen in belangrijke mate ook de perceptie van dit syteem.

De eerste vermelding van het systeem dateert van de jaren 1020$1030^{31}$, de eerste namen van personae dateren van 1040. Zonder exhaustief te zijn, vinden we voor de bisdommen Terwaan, Atrecht,

18 F. D'HOOP ed., Recueil des chartes du prieuré de Saint-Bertin à Poperinghe, Brugge, 1870,5 (nr, 3).

49 W. PETKE, Von der klösterlichen Eigenkirche zur Inkorporation in Lothringen und Nordfrankreich, in Revue d'histoire ecclésiastique, LXXXVII (1992) 3472 en 375-402; DEI.MAIRE, Arras, 108-112.

50 Bijvoorbeeld LAFNEN, Introduction, 355-368; N. HUYGHEBAERT, Examen d'une charte non datée de l'évêque Hardouin de Tournai pour l'abbaye de Saint-Bertin, in Bulletin de l'Instilul de Recherche et d'Histoire des Textes, XV (1967-1968) 277-280; B. JANSSENS DE BISTHOVEN, De houders van het patronaatsrecht in Westvlaamsche parochies, Leuven, 1946, 4-5.

51 HUYGHEBAERT ed., Examen, 290-291; GLERARD ed., Carlulaire de labbaye de Sainl-Beriti, Parijs, 1875, 175-176; DELMAIRE, Arras, 40. 
Doornik en Kamerijk gemakkelijk een 150-tal namen van personae terug voor de periode van 1040 tot $1200^{52}$. Het gaat steeds om clerici, meestal kerkelijke hoogwaardigheidsbekleders die vaak verbonden waren aan een kapittel. Het gaat ook steeds om seculiere geestelijken. In de bronnen vonden we tot nog toe geen reguliere kanunnik noch een monnik en ook geen leken als persona terug. In de gevallen waarin we iets over de sociale achtergrond van deze personae konden achterhalen, gaat het steeds om personen die gelieerd waren met de lokale adel, bijvoorbeeld zonen van burggraven, of met de hoge adel, bijvoorbeeld zonen van de graven van Boulogne en Guînes ${ }^{53}$.

Deze personae waren in het bezit van één of zelfs meerdere bidplaatsen en het spreekt vanzelf dat zij deze bidplaats(en) niet zelf bedienden $^{54}$. Ze streken een deel van de inkomsten op en wanneer een persona wegviel, dan stelde de bisschop in ruil voor een echt verheffingsgeld (redemptio altaris) een nieuwe aan. De rol van de bisschop was hierbij niet anders dan die van een leenheer waarvan een leen va-cant was geworden: met andere woorden een effectief keuzerecht of aanstellingsrecht had hij dus niet. De ontstaansgrond van dit systeem is door een groot tekort aan bronnen moeilijk te achterhalen en blijft enigszins hypothetisch. Het lijkt waarschijnlijk dat er een dubbele ontstaansgrond is die twee soorten personae voortbracht. Vooreerst waren er bidplaatsen die door de leken zelf werden overgedragen aan een familielid of een vertrouweling die tot de geestelijke stand behoorde. Het ging met andere woorden om een vreedzame 'restitutie' van bidplaatsen aan de Kerk, hoewel deze persona de bidplaats ten persoonlijken titel behield (onafhankelijke personae). Een tweede ontstaansreden is te zoeken bij de kerkelijke instanties zelf, met name dat zijzelf aandrongen om een persona bij hun bidplaatsen te voegen. Wanneer bisschop Drogo van Terwaan in 1040 de bezittingen van de Sint-Bertijnsabdij opsomde, voegde hij er ook de namen van de personae van die bidplaatsen aan toe opdat de abdij de altaria (...) absque ullius inquietudinis molestia zou kunnen houden, zolang de personae leefden. Met andere woorden voor de SintBertijnsabdij was de toevoeging van personae aan hun altaria eerder

52 M. CARNIER, Bidplaatsen en parochies in het bisdom Terwaan voóor 1300: een institutionele studie, I, onuitgegeven doctoraatsverhandeling K.U.Leuven, 1996, 126-136.

53 LAMBERTUS ARDENSIS, Historia comitum Ghisnensium, J. HEILER ed., in MGH, SS, XXIV, 1879, 595 en 603; DELMAIRE, Arras, 106.

54 Hoewel Petke misschien een aantal voorbeelden heeft gevonden van personae die zelf hun bidplaats bedienden: PETKE, 379 . 
een gunst, ondanks het feit dat deze personae een deel van de inkomsten afroomden. De personae konden dus blijkbaar steunend op een lokale machtsbasis de werking van de bidplaatsen verzekeren, wat de grote abdijen in die periode zonder steun niet meer konden (bijgevoegde personae). Bij het ontstaan van het systeem van de persona mogen we vermoedelijk ook de termen altare en bodium voegen. $\mathrm{Ze}$ duiken namelijk tegelijkertijd en in dezelfde regio op en gaan over de scheiding van de goederen van de bidplaatsen tussen leken en geestelijken. De scheiding tussen de inkomsten van het altare en de inkomsten van het bodium bestond volgens Abbo van Fleury reeds rond het jaar $1000^{55}$. Het is niet onwaarschijnlijk dat van zodra een bidplaats een persona kreeg, hetzij door toevoeging, hetzij door overdracht, de lekenheer graag twee derden van de gemakkelijk te innen tienden behield en de persona één derde en de moeilijker te innen inkomsten zoals de offergaven $\mathrm{kreeg}^{56}$. Het systeem van de persona of voogd verspreidde zich vrij snel en spontaan in de Noord-Franse bisdommen. Leken stonden hun bidplaatsen aan de kerkelijke sfeer af, zonder dat die echter uit het familiebezit verdwenen. Zonen van lokale heren kregen bij voorkeur deze goederen mee als ze een clericale carrière uitbouwden. Andere altaria bleven echter gewoon in lekenhanden en werden zelfs aan andere leken beleend. Grote druk vanuit kerkelijke hoek om deze bidplaatsen over te dragen, was er in ieder geval niet. Wanneer een 'personaatschap' vacant werd, was het in theorie en ceremonieel de bisschop die een nieuwe aanstelde en daarvoor een hoog verheffingsgeld kreeg. Het is onduidelijk hoe de opvolging in de praktijk verliep. Personae konden zelf voor hun opvolging zorgen. Ze werden opgevolgd door familieleden, indien mogelijk, door hun zonen ${ }^{57}$. Zo ontstonden er in de elfde eeuw misschien zelfs een aantal families van geestelijken bij wie zich een ruim bezit

55 DELMAIRE, Arras, 110-111.

56 Delmaire overschat in mijn ogen echter de bischoppelijke slagkracht als hij deze splitsing ziet als een soort wapenstilstand tussen kerk en leken. Het altare werd zo door de kerk gerecupereerd (volgens hem door de persona als een bisschoppelijke vertrouweling), het bodium bleef in handen van de leken (IBIDEM). Het is echter onwaarschijnlijk dat de bisschop circa 1000 massaal leken kon overtuigen om vrijwillig een deel van hun parochiale inkomsten af te staan.

57 Personae waren clerici, maar hadden niet noodzakelijk de hogere wijdingen ontvangen. Bovendien was er tijdens de elfde eeuw geen cenduidige celibaatsverplichting. Werimboldus en zijn zoon Airulfus waren bijvoorbeeld tezamen personae van Angre (bisdom Kamerijk) (J.M. DUVOSQUEL, Les chartes de donation émanant des évếques de Cambrai au XIe-XIle siècles éclairées par les obituaires. A propos d'un usage grégorien de la chancellerie épiscopale, in Hommages à la Wallonie, Brussel, 1981, 150 en 152). 
van kerkelijke goederen centraliseerde. Zoals een leenheer kon de bisschop wel beschikken over de personaatschappen die geen vanzelfsprekende opvolger hadden.

Omdat bij het herstel van een sterker wereldlijk en bisschoppelijk gezag de oorspronkelijke beschermingsfactor overbodig werd, werd het systeem naar het einde van de elfde eeuw steeds meer als parasitair beschouwd. Geestelijken streken als persona belangrijke inkomsten op zonder veel tegenprestaties. Daarenboven werden de lokale kerken financieel reeds sterk bevraagd. Per slot van rekening konden zowel bezitter, de lekenheer, de persona, de parochiepriester en de bisschop (via het verheffingsgeld) inkomsten uit deze kerken halen. Vanuit kerkelijk 'Gregoriaanse' hoek werd er tegen het systeem geageerd. Dit vond onder andere zijn neerslag in een aantal concilieteksten (vooral het concilie van Clermont van 1095 is belangrijk), maar het systeem zelf werd nooit van hogerhand afgeschaft. Het doofde gedurende de twaalfde en dertiende eeuw spontaan bijna volledig uit omdat de meeste partijen er geen voordeel meer bij hadden. De abdijen hadden geen bescherming meer nodig en de bisschop mocht door het concilie van Clermont geen verheffingsgeld meer innen. De onafhankelijke personae hadden wel nog een zekere toekomst. Gedurende de twaalfde en dertiende eeuw attesteren we ze zoals gezegd nog frequent. Alleen gebeurt dit meestal juist in die oorkonde waarin ze hun altaria, liber, aan een kapittel of een abdij overdroegen, m.a.w. wanneer die bidplaats daarna geen persona meer had. De snelheid waarmee het systeem verdween, verschilde van bisdom tot bisdom en binnen een bisdom van regio tot regio. Het gebeurde het snelst in de hervormingsgezinde bisdommen van Terwaan, Kamerijk en Atrecht, maar blijkbaar een stuk trager in Doornik. Tegen de veertiende eeuw, zo blijkt uit de pouillés, was het systeem marginaal geworden. Kamerijk had er nog circa 55, Atrecht 16. Terwaan $19 \mathrm{en}$ in Doornik, dat zijn achterstand volledig had opgehaald, was het zelfs volledig verdwenen. Voor Terwaan moet dit cijfer reeds circa 1200 bereikt zijn (een kleine $4 \%$ van alle bidplaatsen). Vaak lagen de kerken met personae gegroepeerd. In het bisdom Terwaan bleef de regio van Fauquembergues lange tijd vrij resistent. In het bisdom Kamerijk waren het vooral de noordelijke dekenijen waar de persona lang actief bleef (Antwerpen, Aalst, Halle, Brussel). De bidplaatsen waren dus in de eerste helft van de elfde eeuw in handen van leken, personae of kapittels en abdijen vaak onder voogdij van een persona. In de tweede helft van de elfde eeuw en tijdens de twaalfde eeuw zou er een nieuwe wijziging in het bezit optreden. Heel wat 
bidplaatsen werden overgedragen, wat onder andere de talrijke overdrachtsoorkonden in de abdij- en kapittelarchieven getuigen. De klassieke thesis in de literatuur verdedigde een overdracht, eigenlijk een echte restitutie van de meeste bidplaatsen door de berouwvolle lekenbezitters aan de kerk. Chevalier stelde voor het bisdom Tours echter vast dat de vele overdrachten niet samenvielen met de 'Gregoriaanse' hervormingsperiode en dat 'Gregoriaanse' motieven al evenmin van tel waren ${ }^{58}$. Duvosquel heeft bovendien aangetoond dat het bronnenmateriaal dat op het eerste zicht de bisschop bij deze overdrachten een grote rol toekent, weinig betrouwbaar is en zelfs ronduit misleidend ${ }^{59}$. Achter een overdracht die procedureel door de bisschop gebeurde, zat meestal een derde persoon, vaak een persona. Deze opmerkingen blijken voor alle Noordfranse bisdommen te gelden.

Voor het bisdom Terwaan hebben we tussen 941 en circa 1250 weet van 240 overdrachten van 233 verschillende bidplaatsen ${ }^{60}$. De tendens van verandering van bezitter startte er vanaf circa 1060 , kende zijn hoogtepunt in de eerste helft van de twaalfde eeuw, bleef ook voor de tweede helft zeer hoog, in tegenstelling tot bijvoorbeeld het bisdom Atrecht, en doofde tenslotte geleidelijk uit tijdens de dertiende eeuw ${ }^{61}$. De overdrachten waren in de praktijk vooral schenkingen, zeker tijdens de elfde en de eerste helft van de twaalfde eeuw. Daarna duiken ook andere vormen van overdracht op zoals overdrachten tegen een jaarlijkse cijns, verkopen of verpandingen. Het resultaat van deze overdrachten in het bisdom Terwaan was dat rond 1200 , zoals gezegd, de personae $(3,8 \%)$ en de leken $(3,2 \%)$ nog slechts een marginale groep bezitters van bidplaatsen waren. Het was vooral de ordo canonicus $(49,4 \%)$ die de grootste bezitter was geworden, netjes opgedeeld tussen seculiere en reguliere kapittels. Het kathedraalkapittel was de grootste bezitter van altaria (ca $15 \%$ ), de andere seculiere kapittels hadden gemidddeld relatief weinig bidplaatsen in bezit. De reguliere kapittels hadden gemiddeld meer bidplaatsen ( 7,7 per instelling). De benedictijnen hadden iets meer dan een derde van alle bidplaatsen en per instelling ook een groter aantal bidplaatsen (gemiddeld 14,8). De bisschop tenslotte had circa

58 B. CHEVALIER, Les restitutions d'églises dans le diocèse de Tours du Xe au XIIe siècle, in Mélanges offerts à Edmond-René Labande, Poitiers, 1975, 129-145.

59 DUVOSQUEL, Charles.

60 Dus nog niet de helft van het aantal bidplaatsen die er in het bisdom Terwaan bestonden. (CARNIER, Repertorium, 285).

61 DELMAIRE, Arras, 104 en 114. 
1200 een 27-tal bidplaatsen (5,2\%), maar hij had zijn aantal anderhalve eeuw later wel opgedreven tot $67(12,5 \%)$. Globaal kunnen we stellen dat iedere ordo, met uitzondering van de cisterciënzers belangstelling had voor het bezit van bidplaatsen ${ }^{62}$. Het groot aantal verschillende religieuze instellingen binnen het bisdom drukte zich ook uit in het bezit van de bidplaatsen. Het bezit was met uitzondering van de grote instellingen zoals de Sint-Bertijnsabdij, de bisschop en het kathedraalkapittel ook vooral lokaal geconcentreerd. De abdij van Sint-Winnoksbergen bezat bijvoorbeeld 18 bidplaatsen die allemaal in de dekenij Sint-Winnoksbergen lagen.

De redenen voor deze overdrachten zijn niet makkelijk te achterhalen, al blijkt wel dat zogenaamde 'Gregoriaanse' motieven, namelijk een schuldgevoel of een druk door de Kerk nauwelijks meespeelden. Verwijzingen in de overdrachtsoorkonden naar canonieke rechtsregels om een overdracht te verantwoorden komen niet voor. Wel zien we een correlatie tussen de overdracht van bidplaatsen en het ontstaan van nieuwe kapittels of abdijen. Het bisdom Terwaan en de omringende bisdommen kenden namelijk in de tweede helft van de elfde eeuw en tijdens de eerste decennia van de twaalfde eeuw een enorme toename van het aantal religieuze instellingen ${ }^{63}$. Een paar voorbeelden. De abdij van La Capelle ontstond circa 1095 en had circa 1100 reeds 5 bidplaatsen, de abdij van Andres was omstreeks 1084 ontstaan en had in 11107 bidplaatsen. Het kapittel van Voormezele, ontstaan in 1069, had bij zijn regularisatie in 11007 bidplaatsen. Het reguliere kapittel van Waten, gesticht circa 1072 had circa 110013 bidplaatsen. Het reguliere kapittel van Veurne, ontstaan circa 1120 en later aangesloten bij Premontré had circa 1150 7 bidplaatsen in bezit, de premonstratenzers van de SintAugustinusabdij bij Terwaan, opgericht in 1131 hadden circa 1150 5 bidplaatsen. Het groot aantal overdrachten had dus in belangrijke mate te maken met het leggen van een voldoende materiële basis voor de nieuwe instellingen. Een bidplaats was met andere woorden het goed bij uitstek om de materiële basis van een nieuwe abdij of kapittel te verzekeren. De verantwoordelijken voor deze overdrachten moeten dus bij de begunstigers of stichters van de nieuwe abdijen of kapittels gezocht worden, met andere woorden bij de toenmalige wereldlijke en kerkelijke elite: graven, hogere adel, bisschoppen en hogere geestelijkheid vaak in hun hoedanigheid van personae.

62 De cijfers voor het bisdom Atrecht zijn gelijkaardig (DELMAIRE, Arras, 93).

63 Een dertigtal voor het bisdom Terwaan. 
Voor het schenken van deze bidplaatsen waren vaak voorbereidende transacties nodig. De heer van Ardres moest bijvoorbeeld voldoende compensaties aan de persona van Ardres geven, vooraleer die zijn rechten wou opgeven op het altare dat de heer aan het nieuw op te richten kapittel van Ardres wou schenken ${ }^{64}$. De bisschop speelde bij deze overdrachten meestal geen doorslaggevende rol, maar hij was globaal wel bekommerd om de leefbaarheid van de abdijen en kapittels van zijn bisdom en trad af en toe vanuit deze optiek op.

\section{De bediening}

Het is moeilijk om vóór de dertiende eeuw een profiel van de bedienaar van de parochies op te stellen. Over een aantal uiterlijk aspecten zijn we iets beter ingelicht. Zo was de aanstelling van een pastoor procedureel vrij eenvoudig. De bezitter koos hem en de bisschop stelde hem aan. Zeker vanaf het concilie van Clermont (1095) was het spirituele en het temporele ook op parochiaal vlak strikt opgedeeld. De bedienaar was voor het materiële van zijn functie afhankelijk van de bezitter, voor het spirituele van de bisschop. De bisschop verleende de gekozen kandidaat de cura animarum. Dit was ook zo indien de bedienaar een kanunnik of een monnik was van de instelling die de bidplaats bezat. Omdat beide sferen in principe weinig raakpunten hadden, was de situatie in de praktijk werkbaar en aan weinig conflicten onderhevig. Enkel bij benoeming en afzetting vonden beide sferen elkaar. De bisschop waakte erover dat de kandidaat geschikt (idoneus) was, in de eerste plaats of hij wel priester was of het binnenkort zou worden en of hij wel de geschikte leeftijd had ${ }^{65}$. Aangezien de bisschop sowieso de priesters wijdde, had hij langs deze weg nog een zekere invloed. Globaal kunnen we echter stellen dat de invloed van de bisschop eerder klein was. Een aantal belangrijke instrumenten om zijn parochiepriesters onder controle te krijgen en te houden, bezat hij niet. Hij leidde ze niet op, hij koos ze niet en een priester afzetten was weinig vanzelfsprekend. Bisschop en bezitter konden maar bij uitzondering een seculier priester vervangen: bij te grote excessen, zinsverbijstering of indien zou blijken dat hij geen priester was.

65 Traditioneel 30 jaar, maar het derde concilie van Lateranen (1179) schreef 25 jaar voor. 
Over de opleiding van de parochiepriesters weten we weinig. Het graafschap Vlaanderen was een gebied met een grote dichtheid aan abdijen en kapittels en dus met veel abdij- en kapittelscholen, maar voorbeelden van parochiepriesters die er een opleiding kregen, zijn er niet. Dit lijkt echter plausibel, temeer daar het voor de bezitter een ideale gelegenheid was om de bedienaars van haar kerken zelf te vormen en een stevige band met hen te leggen. De parochiepriesters die we vanaf de dertiende eeuw attesteren, waren in ieder geval voldoende geletterd. In het bisdom Terwaan en ook in het bisdom Doornik werden een aantal als magister bestempeld ${ }^{66}$ en dat zowel op het platteland als in de stad ${ }^{67}$. Parochiepriesters stelden verslagen op voor de bisschop en maakten akten van de transacties die voor hen hadden plaatsgevonden. De parochiepriester van Ardres stelde overigens een kroniek op die gebaseerd was op een stevig bronnenonderzoek en getuigt van een grote eruditie ${ }^{b 8}$. Deze voorbeelden tonen aan dat het om een groep gaat die naar de normen van de tijd een goede intellectuele vorming had genoten. In hoeverre de pastoor theologisch en pastoraal goed opgeleid was, is dan weer een andere vraag. De belangrijkste toenmalige instrumenten om dit te realiseren, waren de bisschoppelijke en decanale synoden, die zeker reeds tijdens de elfde eeuw bestonden, maar vermoedelijk pas na het vierde Lateraans concilie door de bisschop effectief als element van centralisatie werden gebruikt ${ }^{69}$. De concrete werking en de doorstroming naar het lokale niveau blijft echter moeilijk te achterhalen.

De sociale positie van de parochiepriester is door gebrek aan bronnen moelijk te achterhalen. Over het economische draagvlak worden we af en toe ingelicht. We zien pastoors geregeld in eigen naam betrokken bij transacties van onroerende goederen. Het spreekt voor zich dat het bronnenmateriaal hierover per definitie eenzijdig is. Parochiepriesters zonder veel middelen zullen we hier natuurlijk niet zien verschijnen. In ieder geval, zelfs pastoors van onooglijke plattelandsparochies verdeelden een behoorlijk bezit in hun testament $^{71}$, anderen stichtten jaargetijden of zelfs kapelanieën ${ }^{71}$. De pas-

66 Delmaire stelde voor het bisdom Atrecht echter een miniem aantal magistri vast (DELMAIRE, Arras, 144 noot 20).

67 Een paar voorbeelden: Diksmuide, Esen, Langemark, Waasten, Oostvleteren (CARNIER, Repertorium, 46, 63, 119, 172, 241).

68 LAMBERTUS ARDENSIS, o.C.

69 Cf. II. PI.ATELLE, La paroisse et son curé jusqu'à la fin du XIHe siècle. Orientations de la recherche actuelle, in L'encadrement religieux des fideles au Moyen-Age et jusqu'au Concile de Trente, Parijs, 1984, 21.

70 De pastoor van Koksijde in 1271 (CARNIER, Repertorium, 107). 
toor van Langemark had met eigen kapitaal een hospitaal opgericht en probeerde er een clarissenklooster van te maken ${ }^{72}$. Een andere parochiepriester was één van de grote stimulators, ook financieel, van de cisterciënzerinnenabdij van Blendecques ${ }^{73}$. Het is onmogelijk na te gaan in hoeverre deze 'rijkdom' uit familiebezit kwam, maar in ieder geval is het beeld dat we van de parochiepriester in het graafschap Vlaanderen tijdens de dertiende eeuw hebben dat van een bemiddeld man. De carrière is al even moeilijk te achterhalen. Het ziet ernaar uit dat de meeste pastoors tijdens de dertiende eeuw een lange loopbaan binnen dezelfde parochie uitbouwden ${ }^{74}$. Een aantal parochiepriesters schoven wel door naar seculiere kapittels ${ }^{75}$. Tijdens de twaalfde en dertiende eeuw waren de pastoors ook vooral actief in de regio waaruit ze zelf afkomstig waren.

Over het morele niveau van de pastoor kan vóór de vijftiende eeuw weinig zinnigs verteld worden. Een paar gegevens zijn er wel bewaard, maar die zijn te disparaat om over een dergelijk cultuurgebonden fenomeen iets gefundeerds neer te schrijven. Pas vanaf de vijftiende eeuw krijgen we in het bisdom Doornik door de rekeningen van de officialiteit hierop enig zicht ${ }^{76}$. Het is in ieder geval gevaarlijk om het onderhoud van de celibaatsverplichting als lakmoesproef te zien voor de kwaliteit van de parochiepriesters ${ }^{77}$.

De parochiepriester werd in zijn parochie soms bijgestaan door één of meerdere helpers: kapelaans en kosters. Onder de benaming

71 De pastoor van Sint-Winnoksbergen in 1215 (A. PRUVOST ed., Chronique et cartulaire de l'abbaye de Bergues-Saint-Winoc, Brugge, 1875, 191-192).

72 E.I. STRUBBE, De Clarissenabdij te Langemark (1255-59), in: HEm, LXXXVII (1950) 182-188.

73 G. BERINGS, Cinq abbayes cisterciennes en Flandre Française. Fondation et histoire des premières décennies, in: Cîteaux, commentarii cistercienses, XLV (1994) 67.

74 Dit is een moeilijk onderzoek door de schaarste van de bronnen en door de vele homoniemen. Een Nicolaas was in ieder geval pastoor van Spycker van 1244 tot 1269 en een magister Johannes de Rexpoede was minstens van 1260 tot 1277 pastoor van Merckeghem. Andere voorbeelden van een carrière van minstens tien jaar in CARNIER, Repertorium, 45-46, 105, $164 \mathrm{cn} 261$.

75 Een zekere Nicolaas van Berkel die zeker in 1278 deken van het SintWalburgakapittel van Veurne was, was tenminste van 1248 tot 1269 pastoor van Grevelingen.

76 Cf. als voorbeeld voor een van haar vele publicaties hierover: M. VLEESCHOUWERS-VAN MELKEBEEK, Mandatory Celibacy and Priestly Ministry in the Diocese of Tournai al the end of the Middle Ages, in: Peasants and Townsmen in the Middle Ages. Studia in honorem Adriaan Verhulst, Gent, 1995, 681-693.

77 Het celibaat rakte pas algemeen in voege sedert de eerste helft van de twaalfde eeuw. Lambertus van Ardres had een eeuw later bijvoorbeeld zelf nog zonen die hem opvolgden, terwijl we anderzijds nooit weten wanneer iemand hogere wijdingen had ontvangen. 
kapelaan zit een vrij heterogene groep van clerici verborgen die min of meer met de parochiale structuur waren verbonden. Er moet een wezenlijk onderscheid gemaakt worden tussen de helper van de pastoor en de 'echte' kapelaan, die over een eigen beneficie beschikte: de bediening van een kapelanij. De eerste werd door de pastoor zelf betaald, moest de taak van de pastoor verlichten en werd zodoende volledig in het parochiale werk ingeschakeld. De tweede had een eigen beneficie met een strikt omschreven taak, waar hij zich best aan hield om geen problemen met de pastoor of de bezitter te krijgen. In de praktijk waren beide soorten niet altijd even strikt gescheiden: de kapelaan was bijvoorbeeld verantwoordelijk voor een aantal misstichtingen en werd daarvoor door zijn beneficie betaald, maar trad tegelijk ook nog als helper van de pastoor op $^{78}$.

De koster was verantwoordelijk voor de voorbereiding van de misdiensten. Zo had hij bijvoorbeeld ook de zorg over de liturgische voorwerpen, waarvoor hij in principe met zijn eigen vermogen borg stond.

\section{De inkomsten van de parochie}

Parochiale inkomsten als dusdanig bestonden eigenlijk niet. $\mathrm{Er}$ waren meerdere instanties die inkomsten uit de parochie haalden en die als parochiale inkomsten kunnen worden beschouwd. Zowel de pastoor als de bezitter, de parochianen en in mindere mate de bisschop en zijn vertegenwoordigers streken er inkomsten op. Het gaat hoofdzakelijk om tienden en offergaven, maar ook om legaten en om de dotatie van de parochie. Al deze inkomsten zijn specifiek voor het parochiale niveau, maar de concrete inning en verdeling waren lokaal gebonden.

Tienden waren nog maar gedeeltelijk, en dan nog vooral onrechtstreeks, inkomsten die de werking van de parochie ten goede kwamen. De kerkelijke wetgeving rond de tienden werd goed bestudeerd ${ }^{79}$, de implicaties daarvan op het lokale vlak veel minder. Tienden werden

78 Cf. ook DELMAIRE, Paroisses rurales, 72-73.

79 P. VIARD, Histoire de la dîme ecclésiastique, principalement en France, jusqu'au décret de Gratien, Dijon, 1909; IDEM, Histoire de la dime ecclésiastique dans le royaume de France au XIle et XIIle siècle (1150-1313), Parijs, 1919;G. CONSTABLE, Monastic tithes from their origin to the twelfth century, Cambridge, 1964; F.L. GANSHOF, La dîme monastique, du IXe à la fin du XIle siècle. A propos d'un livre récent, in Cahiers de civilisation médiévale, XI (1968) 413-420. 
in ieder geval op agrarische producten geïnd. Tiendeninning op producten van handelaars en ambachtslui bleef hier louter theoretisch. In de praktijk ontstond een onderscheid tussen grote en kleine tienden, dat weliswaar nergens kerkrechterlijk was bepaald. Onder de grote tienden verstond men de tienden op grote gewassen, meestal met stengel, of ook kortweg graantienden genoemd. Kleine tienden werden in principe op al de rest geheven: vleestienden (varkens, lammeren), vogeltienden (haantjes en hennen, ganzen, zwanen, eenden), vistienden (vooral haring), tienden op ambachtelijke gewassen (vlas, wol, hop, meekrap, brem, distels), groentetienden (o.a. rapen, bonen, erwten), fruittienden, tienden op honing en was, en tienden op voedergewassen als hooi en wikke ${ }^{80}$. Wat precies aan tiendenbetaling onderhevig was, was bepaald door de traditie en kon van parochie tot parochie en zelfs van perceel tot perceel verschillen. Vooral de inning van kleine tienden was vaak ingewikkeld.

In de bisdommen van het graafschap Vlaanderen was tijdens de volle middeleeuwen normaal één derde van de grote tienden in handen van de bezitter van de parochie. Deze moest die inkomsten niet rechtstreeks gebruiken voor de werking van de parochiekerk, maar ze kwamen in ieder geval nog ten goede aan een instantie die bij het parochiale niveau was betrokken. De twee andere derden waren meestal in bezit van een externe tiendenheffer. Dit was vaak nog een leek, hoewel in de dertiende eeuw een belangrijk aandeel van deze tienden door de lokale adel of door ridderfamilies wegens geldgebrek aan een kerkelijke instantie (bisschop, kapittel, abdij) werd verkocht, zonder dat die instantie echter enige verantwoordelijkheid had voor de werking van de lokale bidplaats. Deze twee derden van de externe tiendenheffers versnipperden bovendien door vererving en bruidschat meestal nog tot kleinere stukken, soms zelfs tot twaalfde en achttiende delen. Kleine tienden werden vaker nog voor de parochie zelf gebruikt, bijvoorbeeld als deel van het inkomen van de bedienaar. Deze was namelijk beter dan de bezitter in staat om de ingewikkelde lokale situatie te kennen waarop al dan niet tienden konden worden geïnd en om deze regeling ook te laten respecteren. De indeling tussen grote en kleine tienden werd doorkruist door novale tienden die in het graafschap Vlaanderen veel voorkwamen. Dit waren tienden die geïnd werden op gebieden waarvan men zich nog kon herinneren dat ze ooit nog woest waren geweest. Voor novale tienden waren bovendien vaak andere verdelingsprincipes van toe- 
passing. Dit gebrek aan een stevig criterium zorgde ervoor dat hierrond zeer vele twisten werden gevoerd ${ }^{\text {11. }}$.

Tienden waren in de praktijk domaniale inkomsten en werden ook als dusdanig beschouwd. Het waren belangrijke bronnen van inkomsten en daarom oorzaak van vele twisten. De tienden waren bovendien volledig ingebed geraakt in de toenmalige familiale en feodale realiteit, wat vooral voor kerkelijke instanties een probleem vormde. Die konden namelijk wel beschikken over mooie privileges waarin hun tiendenbezit in bevestigd was, maar in de praktijk was het vaak bijzonder moeilijk om deze aanspraken ook in de praktijk om te zetten. Vaak was er namelijk een adellijke familie of diens leenman die reeds sinds mensenheugenis deze tienden inde en die dan ook niet van plan was om die zonder slag of stoot af te geven aan een abdij of een kapittel die met een rechtstitel kwam aangezwaaid ${ }^{52}$. Ondanks het feit dat in de praktijk tiendenbezit niet als iets wezenlijks verschillend werd beschouwd dan ander goederenbezit, hadden tienden echter een dubbel statuut. Zowel het wereldlijk als het kerkelijk recht pretendeerden hierop geldingskracht te hebben. De pogingen van canonisten om tienden als een spiritueel goed te beschouwen, had in de praktijk echter weinig invloed. Het waren en bleven in de eerste plaats domaniale goederen met groot economisch belang. In de praktijk bleef er dan ook niets meer over van de oorspronkelijke bestemmelingen van de tienden, namelijk bedienaar, fabriek, armen en bisdom. In de Noord-Franse bisdommen was het niet de gewoonte dat de bisschop recht had op een deel van de tienden, zodat er hier ook geen lange conflicten zijn geweest tussen de bisschop die de controle over zijn canonieke deel van de tienden nastreefde en de traditionele tiendenheffers. De tienden die de bisschop inde behoorden dan ook steeds tot zijn eigen domaniaal patrimonium. Enkel de pastoor had als enige van de traditioneel rechthebbenden nog recht op een deel van de tienden, maar dit was in iedere parochie door de gewoonte verschillend geregeld.

Tienden waren tijdens de elfde eeuw bijna volledig in lekenhanden en zouden vanaf dan geleidelijk in kerkelijke handen komen. Op het einde van de elfde en tijdens de twaalfde eeuw waren het vooreerst de tienden die met het altare verbonden waren die in kerkelijke handen kwamen. Het zou echter tot de dertiende eeuw duren vooraleer

81 Cf. I. SCHOUPS, Bisschoppelijke aanspraken op de novale tienden: Doornik, $12 e-14 e$ eeuw, in: HEm, CXVIII (1981) 153-171.

82 M. CARNIER, Tienden in het graafschap Vlaanderen tijdens de twaalfde eeuw: het voorbeeld van Reninge, in: HEm, CXXXII (1995) 97-116. 
tienden massaal in kerkelijke handen kwamen. Dit blijkt zowel in de bisdommen Atrecht, Luik en Terwaan ${ }^{83}$. Zeker de helft van de overgedragen tienden werden verkocht. Het profiel van de verkoper is niet eenduidig, maar vaak ging het om een lokale notabele die zijn tienden in leen hield, maar die zelf niet noodzakelijk van adel was of uit een ridderfamilie kwam. De koper was voor deze leek eigenlijk maar van secundair belang. In de praktijk ging het om een kerkelijke instelling die geïnteresseerd was en het nodige kapitaal had ${ }^{84}$. In het noordelijk deel van het bisdom Terwaan waren dit bijvoorbeeld vooral reguliere kapittels die in deze regio veel voorkwamen. Seculiere kapittels en benedictijnerabdijen waren op dit domein tijdens de dertiende eeuw iets minder actief, deels omdat zij op dat ogenblik reeds een belangrijk tiendenbezit hadden.

Offergaven waren de inkomsten die gelovigen zowel in natura als in geld al dan niet vrijwillig aan de lokale kerk gaven. Ze moesten dienen om de werking van de bidplaats te verzekeren of als een soort van betaling voor het krijgen van de sacramenten ${ }^{85}$. Enige tarifiëring in verband met de offergaven vaststellen is tijdens de twaalfde en dertiende eeuw door het beperkte bronnenmateriaal niet mogelijk.

Andere parochiale inkomsten waren nog de dotatie van de kerk, maar ook die verschilde van parochie tot parochie. Meestal behoorde de pastorij hierbij. Bij de oprichting van de parochie Sheerwillemskapelle bijvoorbeeld kreeg de pastoor behalve een degelijke woning ook nog 5,5 gemet grond, een koe, drie schapen en een vederbed met twee linnen lakens ${ }^{86}$. Dit patrimonium werd vaak nog uitgebreid door legaten waar tegenover meestal wel een dienst stond, zoals een jaargetijde ${ }^{87}$.

83 C. RENARDY, Recherches sur la restitution ou la cession des dîmes aux églises dans le diocèse de Liège du XIe au début du XIVe siècle, in: Le Moyen Age, LXXVI (1970) 205261; Delmaire, Arras, 132-135 en 140; CARNIER, Bidplaatsen, 273-289.

84 De verkoopprijs van de tiende lag bij de verkoop van een tiende van Vlamertinge in 1257 op 13 geschatte jaaropbrengsten (CARNIER, Repertorium, 231-232).

85 Dit is eigenlijk een oneigenlijke vorm van offergaven en worden ook stoolrechten of jura stolae genoemd.

86 CARNIER, Repertorium, 201.

87 IBIDEM, 192-193 en 277. 


\section{Besluit}

Het is binnen dit korte bestek onmogelijk om op alle aspecten van het middeleeuwse parochiaal systeem in te gaan. Het blijft een complex fenomeen dat door eenzijdig en weinig homogeen bronnenmateriaal moeilijk te benaderen blijft. Door deze bronnensituatie konden er vrij gemakkelijk interpretaties worden gemaakt die op geen enkele manier door de bronnen worden gestaafd. Vooral een soort van posttridentijns kerkbegrip speelt het onderzoek nog steeds parten, waarbij te veel normatieve elementen werden gebruikt om de reële lokale situatie te benaderen. Doorgedreven lokaal en regionaal onderzoek is dan ook noodzakelijk om dit beeld aan te passen. 
